Check for updates

The BMJ

Cite this as: BMJ2020;370:m2835 http://dx.doi.org/10.1136/bmj.m2835 Published: 14 July 2020

\section{Government faces backlash after care workers are excluded from fast track visas}

Abi Rimmer

The government has been criticised for excluding care workers from being able to apply for visas designed to fast track those coming to the UK to work in the health and care sector.

On 13 July 2020 the Home Office released details of the UK's points based immigration system which will come into effect from 1 January 2021. Under the new system the health and care visa will allow people working in eligible occupations, who speak English, and have a job offer, to come to the UK. ${ }^{1}$

Under this visa route, workers and their families will gain fast tracked entry to the UK with reduced application fees and dedicated support, the government said. Those who are eligible to apply, and their dependents, will also be exempt from paying the immigration health surcharge, a move that has been welcomed by doctors. $^{2}$

Applicants must meet a salary threshold of $€ 25600$ (€28 200; \$32 000) to be eligible to apply for the visa, unless they are entering a shortage occupation such as nursing and medicine. The NHS workers union GMB said that this threshold would mean that many NHS cleaners, porters, and support staff won't qualify for the visa.

The government has also faced a backlash because social care workers are not eligible to apply for the visa. Although the Migration Advisory Committee-on whose advice much of the new system is based-recognised the workforce shortage faced by social care in its most recent report ${ }^{3}$ it did not recommend that care workers be added to the list of shortage occupations.

Instead, the committee said that it hoped the government's forthcoming green paper on social care ${ }^{4}$ would provide more clarity on the future of the sector in the UK and contain concrete proposals to improve terms and conditions for care workers.

Reacting to the news, the Labour MP for Tooting, Rosena Allin-Khan, wrote on Twitter, "After months of publicly clapping for carers, last week the PM blamed them for covid deaths and now tells them they're not welcome to live and work here."

Saffron Cordery, deputy chief executive of NHS Providers, said that while the exemption for healthcare workers to the immigration health surcharge was welcome, the lack of support for the social care workforce was concerning. "While conditions for recruiting international staff to the NHS have improved, we continue to be frustrated by the lack of support for our partners in the care sector," she said. "The new points based system is likely to exacerbate the workforce crisis in social care, with the temporary visa route removed and the vast majority of social care professionals still implied to be 'low skilled' and therefore ineligible to apply for a tier 2 visa."

Jennifer Dixon, chief executive at the Health Foundation, said that social care would be left "high and dry" under the new system, at a time when covid-19 had compounded existing workforce problems. "Around $17 \%$ of people working in adult social care in England are non-British nationals, with EU workers now making up about half of those-a share that has increased since 2012-13," Dixon said.

"Even if they were made eligible for the health and care visa, the new system would still mean additional costs and barriers to people from the EU compared with the current system of freedom of movement."

\footnotetext{
Home Office. The UK's points-based immigration system: further details. July 2020. https://assets.publishing.service.gov.uk/government/uploads/system/uploads/attachment_data/file/899755/UK_Points-Based_System_Further_Details_Web_Accessible.pdf.

Rimmer A. Doctors welcome plan to scrap NHS fee for overseas staff. BMJ2020;369:m2073. doi: 10.1136/bmj.m2073 pmid: 32444352

Migration Advisory Committee. Full review of the shortage occupation list. May 2019. https://assets.publishing.service.gov.uk/government/uploads/system/uploads/attachment_data/file/806331/28_05_2019_Full_Review_SOL_FinaL_Report_1159.pdf.

4 Wise J. Social care: pressure mounts for urgent and radical reform. BMJ2019;366:14564. doi: 10.1136/bmj.14564 pmid: 31278072
} 